\title{
Chapter 4: \\ Primary Experientiality
}

Experientiality can only be discussed as a sliding scale between overlapping layers of restrictive, primary, and secondary experientiality; it is a concept that places visitors in a position to experience perceptions and structures of the past. Their role is combined with the experiences of historical people - usually represented collectively, not individually - in the various structures and atmospheres in which they lived. As seen in the previous chapter, there are different forms and layers of restricted experientiality, whether the restriction stems from a linear master narrative, a clear ideology, or an uncritical affirmation of myth and pre-existing cultural memory. In all cases, an argumentative or ideological structure reduces any individual visitor experience of the past. This is often closely related to lack of distantiation. The three museums discussed in this chapter the National WWII Museum in New Orleans, the Oskar Schindler Enamel Factory in Kraków, and the Bastogne War Museum - all simulate real historical events and historical situations; they mimetically indicate that members of certain historical groups could have experienced the past as it is presented in the museum. For all three museums, experientiality surpasses mere argument or ideology. The visitor has the opportunity to be immersed in collective perspectives of the past, with the awareness that the museum is creating a simulation or theatrical performance of the past. The New Orleans WWII Museum operates along the border of restricted experientiality, as it immerses the visitor in a singular narrative as if it were the war's only existing reality. At the same time, the museum's strong focus on oral history and historical witness accounts allows the visitor some room to experience the past beyond the mere staging of ideology. The focus is thus less on historical truth, as visitors are steered toward the feeling that they are experiencing a multitude of collective perceptions of the war. Both the Oskar Schindler Factory (OSF) and the Bastogne War Museum (BWM) are more of hybrids between primary and secondary experientiality. The OSF challenges the visitor to become a time traveler in a historical space, in which they can both observe and immerse themselves in the collective perspectives of, for example, Polish and Polish-Jewish citizens of Kraków. During this experience, the visitor is aware of the theatricality of this time-traveling journey. The BWM allows for the visitor to be immersed alongside fictitious composite characters, while mixing this immersive experience with numerous other sources and forms of distantiation.

Ә OpenAccess. (C) 2020 Stephan Jaeger, published by De Gruyter. (cc) BY-NC-ND This work is licensed under the Creative Commons Attribution-NonCommercial-NoDerivatives 4.0 License. 


\subsection{The National WWII Museum in New Orleans}

The National WWII Museum in New Orleans is a typical American military history museum oriented toward combat and military missions abroad. It functions as a narrative memorial museum that uses a considerable amount of experiential techniques. This is done not in the vein of Williams's idea of commemorating suffering and victimhood (2007), but instead more in the sense that it commemorates war veterans from all branches of the American Forces. Because of its strong mission, one could argue that this museum also belongs in the category of restricted experientiality. At the same time, its strong basis in oral history allows visitors to go beyond a single preconceived narrative. The museum was founded as D-Day Museum in 2000. In 2004, it was designated by the United States Congress as America's official National World War II Museum "with the new mission to portray the full American experience in the war, including its ongoing meaning for global freedom." ${ }^{1}$ The highly popular museum is funded through admission, memberships, and private fundraising. ${ }^{2}$ It caters particularly to war veterans and their families. It focuses almost exclusively on the contribution made by the United States to the Allied victory in the Second World War in both the European and Pacific theaters of war. Its six-part mission statement highlights both the museum's goal of contributing to the "understanding of the history and meaning of America's role in World War II and its relevance for today and for the future" and the museum's objective to "[b]ecome a place for people to understand and feel America's strengths and values." ${ }^{3}$ There is large memorial slab located in front of the Salomon Victory Theater that is indicative of the museum's approach. It tells the story of how New Orleans historian Stephen E. Ambrose conceived of a D-Day museum in New Orleans to narrate the story of American veterans in wake of D-Day. The museum also honors entrepreneur Andrew Higgins, whose New Orleans factories built the landing crafts that were instrumental in delivering Allied forces to shore in Europe and the Pacific

1 Text on memorial slab in front of the Salomon Victory Theater on the Battle Barksdale Parade Ground.

2 It generates high visitor numbers - 754,465 in 2018 (National WWII Museum 2018, 5) and is extremely popular on social media. For years, it has been advertised as a top museum in the USA and in the world on tripadvisor.com; in 2017 it reached the amazing status of being the no. 2 museum in the world (https://www.tripadvisor.com/TravelersChoice-Museums-cTop-g1, accessed 25 March 2018, only after the Metropolitan Museum of Art (MET) in New York; in 2018 it fell to an still impressive eighth place worldwide (same site, accessed 13 October 2019).

3 https://www.nationalww2museum.org/about-us/mission-vision-values (accessed 13 October 2019). 
islands. Ambrose started an oral history collection of interviews with Second World War veterans, which has been under constant development ever since. It has also become the core of the museum collection and the backbone of its exhibitions and research expertise (see also Barnes and Guise 2013).

On the slab, there is a quotation by Ambrose that reads "At the core, the American soldiers knew the difference between right and wrong, and they didn't want to live in a world in which wrong prevailed, so they fought and won, and we, all of us, living and yet to be born, must be forever profoundly grateful.” The founding CEO of the museum Gordon H. 'Nick' Mueller is quoted on the left hand side of the memorial stone as follows: "World War II served as a crucible. All of the human, spiritual, and material resources of our nation were mobilized to defeat authoritarian and racist regimes and to defend freedom. It was a fight to the finish for civilization itself. The American spirit prevailed." This honors the American contribution within a clear moral framework and predefines good and evil regarding the American 'good war' (Terkel 1984; Torgovnick 2005, 59) and the myths highlighting D-Day as American self-liberation (Dolski 2014). The New Orleans WWII Museum has developed its own campus, designed by Voorsanger Mathes LLC, which continues to evolve. Eventually, it will offer about 8,500 square meter (92,000 square feet) of exhibition space. ${ }^{4}$ The pavilion architecture with skywalks has a fairly futuristic look, reminiscent of military industrial design. Consequently, the buildings' interiors are designed pragmatically for exhibition purposes. In addition to the original building, the Louisiana Memorial Pavilion, ${ }^{5}$ the museum has opened the Solomon Victory Theater (2009), the John E. Kushner Restoration Pavilion (2011), the US Freedom Pavilion: The Boeing Center (2012), and the Campaigns of Courage Pavilion (2015). ${ }^{6}$ Throughout the different pavilions, the museum uses the technique of repetition to reinforce factual information about battles, campaigns, equipment, and American soldiers in the war. In this way, a visitor who spends enough time in the museum is consistently exposed to slightly varied narratives of the same themes and events. This technique speaks to the visitor' cognitive and affective capacities; it is less about producing new knowledge than about emphasizing

\footnotetext{
4 http://www.archdaily.com/209361/the-national-world-war-ii-museum-voorsanger-architects, accessed 13 October 2019 (Voorsanger Mathes LLC).

5 It reopened several of its exhibitions after major renovations in 2017.

6 See for a comprehensive history of the New Orleans WWII Museum its "Fiscal Year 2017 Annual Report,” https://www.nationalww2museum.org/sites/default/files/2018-01/annual-report2017-resize.pdf, accessed 13 October 2019. See for further information https://www.natio nalww2museum.org/visit/museum-campus, accessed 13 October 2019.
} 
and possibly enriching generalized knowledge already familiar to the visitor, while reflecting the American gaze and American cultural memory. ${ }^{7}$

The New Orleans WWII Museum is interested in recapturing the American gaze, while contextualizing it within military history and displaying mostly objects of illustrative quality. For example, in the interactive Dog Tag Experience, computer screens - set-up in six stations - allow the visitor to use a digitally enabled 'dog tag' IDs to connect with an individual witness's narrative of the war. Visitors can also collect objects on their dog tag ID, and computer stations feature excerpts from selected oral eyewitness accounts. ${ }^{8}$ Besides its oral history approach, ${ }^{9}$ the New Orleans WWII Museum employs two techniques in particular that create primary experientiality: first, it simulates interior and exterior spaces that American soldiers and commanders would have experienced during military campaigns. This can especially be seen in the museum's 2015 building Campaigns of Courage, which houses the "Road to Berlin" and the "Road to Tokyo" and in the scenic settings used in the "Arsenal of Democracy" exhibition. ${ }^{10}$ Second, it features several elaborate multimedia installations, which are aimed at allowing the visitor to experience war. The "Road to Berlin" exhibition consists of nine sections, five of which are set as explicitly immersive scenes: in sequence and with the American soldiers, the visitor enters a North-African landscape, surrounding them with desert and rocks, and then moves through ancient Italian buildings and ruins during the Italian campaign. This is followed by a Normandy landscape made up of hedges found in the room on the Northwestern European campaign, a snowy forest in the Battle of the Bulge, and lastly, a destroyed Germany. Similarly, the "Road to Tokyo" exhibition on the upper floor of the pavilion features a jungle on the island of Guadalcanal and an immersive mountainscape of the Himalayas.

7 It will be interesting to see whether the new National Museum of the United States Army in Fort Belvoir, VA, expected to open to the public on June 4, 2020, will tell the same universalized story of the American role in the Second World War as the New Orleans WWII Museum. The new US Army Museum aims to tell the story of its soldiers. It features the "Fighting for the Nation Galleries" (its main space), the "Army and Society Gallery," and a specific section for soldiers' stories. It "will honor United States Soldiers - past, present, and future - and provide an interactive educational experience explaining the Army's role in creating and defending our nation, as well as the Army's social initiatives and contributions for more than 240 years” (https://ar myhistory.org/about-the-museum/, accessed 13 October 2019).

8 In the Boeing Center, the visitor can access many interviews in detail.

9 The museum's oral history approach is discussed further in chapter 7 on Holocaust representation in war museums.

10 This includes, among others, a 1942-style home and an immersive Los Alamos environment where the development of the nuclear bomb via the Manhattan Project is documented. 
The last room of the "Road to Berlin" exhibition can serve as model for understanding how the New Orleans WWII Museum creates a hybrid out of primary and secondary experientiality. With the exception of the European/Mediterranean Briefing Room and the little documentary D-Day Theater, ${ }^{11}$ all of the rooms immerse the visitor in the collective gaze of the American soldier in North Africa and Europe. Immediately after the immersive snowy scene in the Battle of the Bulge, the visitor sees an enlarged poster, featuring the city of Cologne in ruins, recognizable from the looming cathedral and destroyed bridges on the river Rhine. The wall poster is embedded in a stage set with building fragments and a looming fire in front of it. The visitor then enters the small first part of the final section, which has been made to look like the interior of a destroyed room in a residential house. The wooden ceiling has holes; the edges of ceiling, tapestry, and wooden floor look burned. On the tapestry, a quotation by an infantryman reads "One cannot go to war and come back normal." The visitor can decide whether this refers to the discoveries of destruction and concentration camps made by American soldiers, or whether it serves as a warning to the Germans that they should not expect their country to remain normal and deserve to have their country in ruins. Upon entering this section's larger main space, the visitor becomes immersed in an outdoor scene of destroyed Germany, containing large posters of Hamburg and Bremen in ruins on the right hand side and Dresden and Berlin on the left. These posters are mounted between staged remnants of ruins that are seemingly still burning. Shadows of the fire fall on the room's stone floor. At the end of the room is a large film screen with stone benches, which provides the main survey film for the section (see fig. 8). ${ }^{12}$ This setting invites the visitor to sit among ruins and watch the film through the gaze of an American soldier. It is narrated in a somber voice, which is occasionally interrupted by quotations from soldiers that are presumably reenacted.

The music and the decisive tone of the narrative voice create some pathos and establish moral values. The events of the film follow the traditional storyline

11 D-Day plays a minor role in the "Road to Berlin" exhibition, since the museum features its original exhibition “The D-Day Invasion of Normandy," revised and re-opened in 2017, on the third floor of the Louisiana Pavilion. This exhibition uses similar techniques to the ones in the Campaigns of Courage Pavilion by simulating the gaze of the American soldier landing in Normandy through enlarged photo posters.

12 The standard technique used in the "Road to Berlin" is to have a survey film in each new section that introduces the visitor to the entirety of the topic through the voice of a narrator, alongside historical pictures and footage. In other words, the visitor receives the same information several times: in the survey panel with a brief text and map, in the chronological photo story with brief captions on wall panels, in the survey film, and in the computer stations with oral witnesses, and possibly through the Dog Tag Experience. 


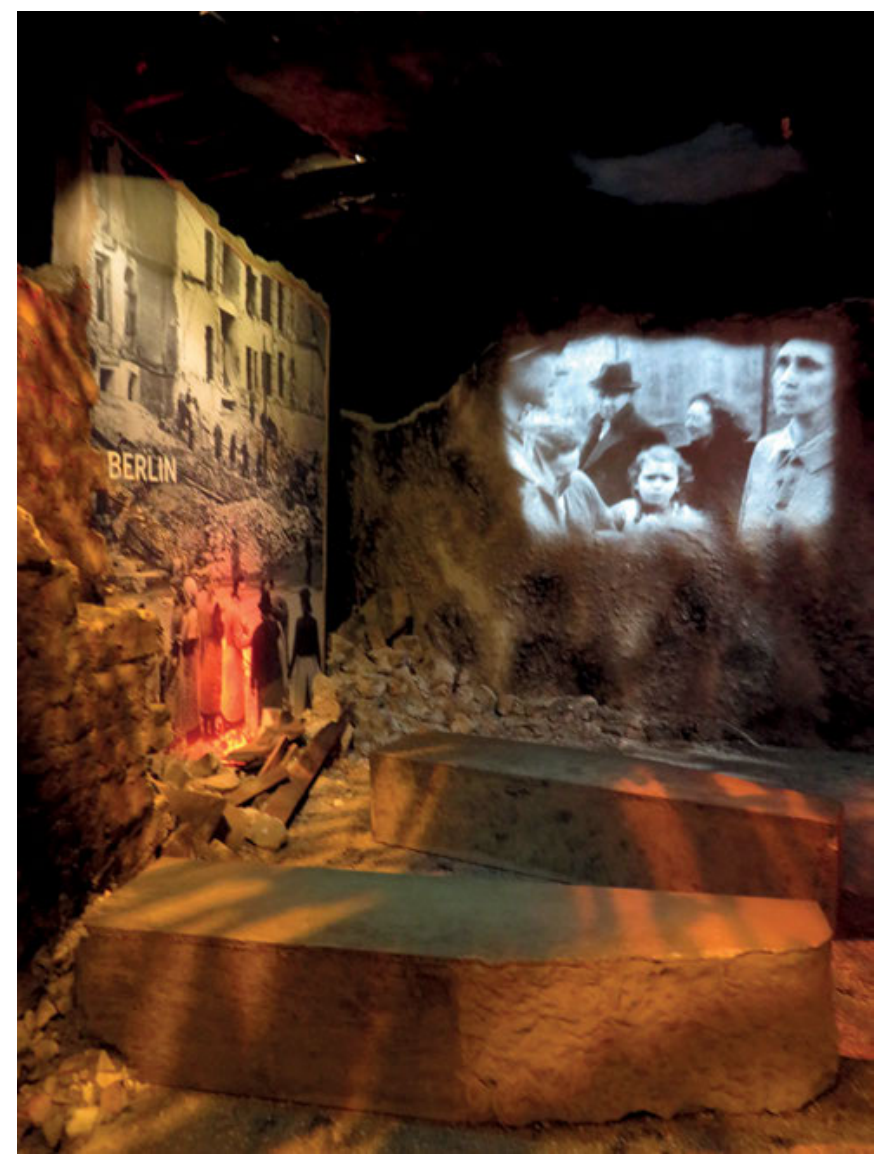

Fig. 8 Immersive film theater in ruins, room "Into the German Homeland" in "Road to Berlin" exhibition. The National WWII Museum, New Orleans (Photo: Author, 2017, courtesy of The National WWII Museum).

regarding the last months of the war featuring a destroyed Germany, the Volkssturm, Hitler sacrificing his people, Americans acting as liberators and not conquerors, the discovery of the concentration camps, Dwight D. Eisenhower and George S. Patton in the Ohrdruf concentration camp, the Nazis' ideology and atrocities, the strategic bombing of the German cities, the meeting of Americans and Russians at Torgau, the Battle of Berlin and the city's surrender, Hitler's suicide, and the unconditional surrender at Reims. Strong statements structure the film's frame, exemplified at the beginning: "There can be only one outcome to this war: Germany's unconditional surrender"; and in the closing statement: "Together, these men and women [the American soldiers] will share a bond of 
pride, courage, sacrifice, forged on the battlefields of Europe and as they fought to free us from the darkest of tyrannies, and restore a sense of hope to the world." The latter corresponds to General Dwight D. Eisenhower's quotation, which the visitor can read upon exiting the gallery: "No other war in history has so definitely lined up the forces of arbitrary oppression and dictatorship against those of human rights and individual liberty."

None of the events narrated in the film or presented through the text panels and objects within the ruins go beyond the knowledge of the typical American soldier. They would have either experienced these events directly - for example, in their fighting the Volkssturm, or the discovery of the camps - or heard about them in the news or through a comrade, as in the case of Hitler's suicide, details of Nazi atrocities, and the final surrender. The visitor, therefore, experiences the collective perspective of the American soldier; the combined representation of all American perspectives together allows the visitor to empathize with their mission, their beliefs, and the challenges they faced. This is constructed primary experientiality, regardless of whether the visitor's historical experience is more likely to resemble American cultural memory today than historical knowledge. Unlike in the Warsaw Rising Museum and the Canadian War Museum, where argument and historical truth restrict strong visitor involvement, the visitor here is necessary as a mediating consciousness to reiterate the collective American gaze. The immersive effect is strongly supported through the computer stations located at the beginning of the section, which are the fifth of the Dog Tag Experience stations. ${ }^{13}$ The visitor can also listen to seven oral witnesses and see a list of items that are relevant for the room's theme. All oral histories relate to wartime events, including the breaking of the Siegfried line, the crossing of the Remagen Bridge, a fight with a fanatical member of the Hitler Youth, and an American soldier unsuccessfully trying to save a baby playing with a hand grenade. The latter event is called "The Cost of War." The close-up collective gaze of the American soldier is intensified through these voices: visitors, who take their time, can immerse themselves even more in the possible views and primary experiences of the American soldier.

The moral mission rendered explicitly by film's and Eisenhower's quotations, as cited above, underline this constructed collective gaze. The museum adds historical facts and information here and there, but does not provide historiographical analysis. In this way, the visitor is not provided with any room

13 There are usually two identical computer stations situated next to each other, which still restricts visitor access immensely. Many visitors pass by the stations or wait to collect artifacts on their dog tag card and listen to their dog tag member identity. However, most visitors did not linger at the stations during my five days of museum analysis in May 2017. 
to question the museum's moral vision. The exhibition consistently reduces its conclusions down to simple factual statements, such as "The Führer would rather annihilate the very people and nation he professes to love than admit defeat." This sentence downplays the racial ideology of Hitler and the Nazis: it focuses on 'loving one's people' and 'being defeated' instead of analyzing the multiplicity of reasons behind the fanatical defense of Germany at the end of the war. In other words, the museum does nothing to help the visitor understand ideology and historical actions. Consequently, it is more important to show trophies such as porcelain and silverware allegedly belonging to Hitler or other high-ranking Nazi officers in the object vitrines of this section than to give historical context to the ideology and crimes of the Nazi regime. It becomes evident that the New Orleans WWII Museum is much more of a memorial museum (commemorating the moral achievement of a 'good war') than a history museum. Its constructed gaze indicates what an American soldier could have thought and brings together a multiplicity of primary experiences (usually as un-reflected memories) within this collective construct.

A final example from outside the museum can confirm the effectiveness in which the museum immerses twenty-first-century visitors in its historical settings. On the corner of Canal Street and Magazine Street, visitors to New Orleans can find an immersive bus stop. ${ }^{14}$ Instead of a poster advertising the museum and one of its major attractions, the front, back, and sides of the bus stop are designed with imagery that reminds visitors of the ruins analyzed above, in the last room of the "Road to Berlin." The back is transparent and displays a poster of the ruins of Cologne featuring the Cologne Cathedral. This makes it seem like passengers waiting at the bus stop or walking/standing behind it are part of the scene (see fig. 9). Thus, the museum foreshadows its primary experientiality through its advertising and indicates the ways in which it bridges past and present.

The second way in which the New Orleans WWII Museum creates experientiality is through its multimedia installations. The Final Mission: USS Tang Submarine Experience in the Boeing Pavilion immerses visitors in the last mission of the Tang in the Pacific. After successfully attacking a Japanese convoy in the Formosa Strait on the South China Sea, the Tang is sunk by its own torpedo. Only nine out of eighty-seven men on board survived. The visitors (maximum twenty-seven per experience) are led into the U-boat, and many are asked to perform specific tasks at their stations to navigate through the battle. In reality, most visitors watch the panoramic view of the South China Sea through the ceiling of

14 Based on a visit in May 2017. 


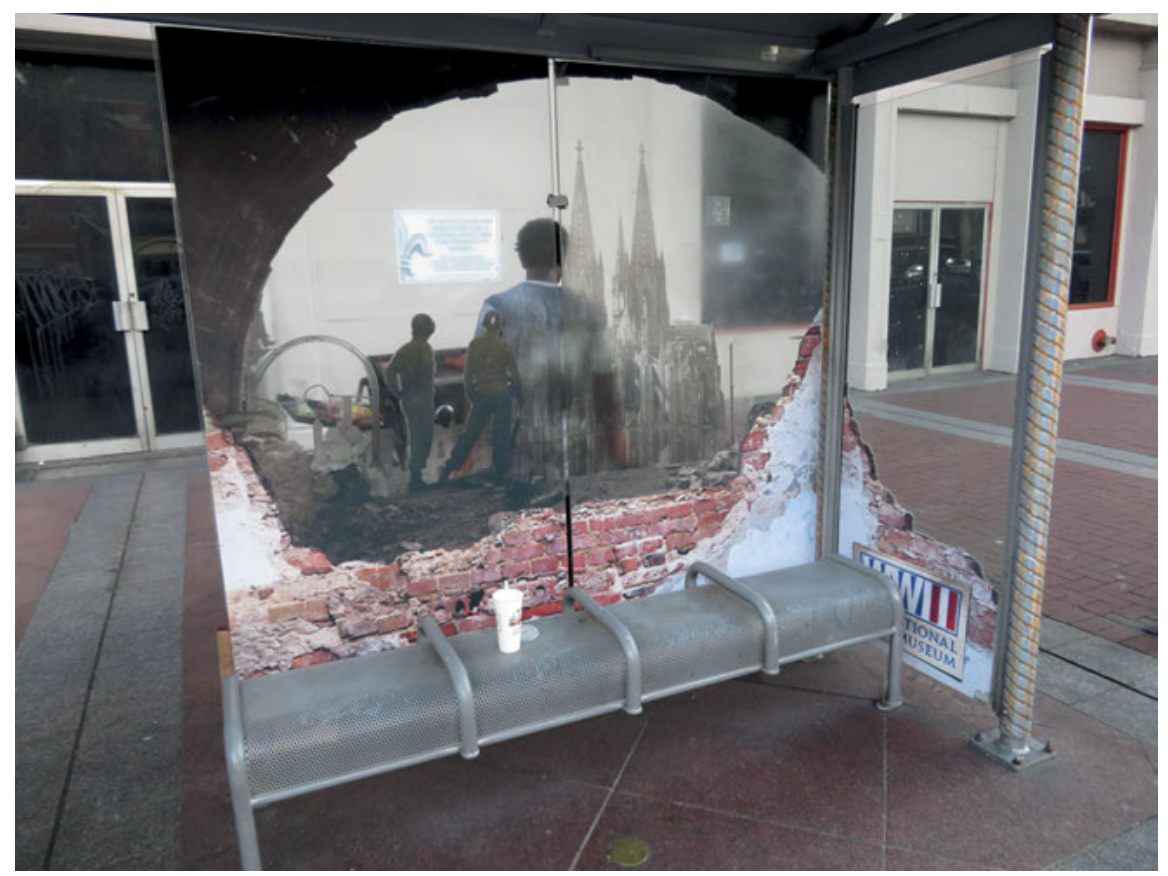

Fig. 9 Immersive bus stop in the ruins of Cologne. Advertising for The National WWII Museum, Canal Street, New Orleans (Photo: Author, 2017).

the multimedia installation, while these battle contributions remain more of a gimmick..$^{15}$ Nobody, despite the explosions at the end, will feel as if they have come close to participating in an actual battle and even less to being in danger (one can check at the end whether the crewmember that one was assigned survived). Thus, USS Tang experience is a mixture of entertainment, storytelling, and the commemoration of a heroic boat and crew.

To understand how multimedia installations contribute to primary experientiality, the L.W. 'Pete' Kent Train Car Experience is more interesting. It is located in the entrance hall of the Louisiana Pavilion, set up in 2014. Next to the admission cashiers, visitors can undergo this train car experience in four and a half minutes and enter a Union Pacific train carriage "in the footsteps of new recruits on their way to war." ${ }^{16}$ The inscription of the Nebraskan town North Platte on the

15 The area following this performance is mainly geared toward the commemoration of perished submarine crews.

16 https://www.nationalww2museum.org/visit/museum-campus/louisiana-memorial-pavilion/ train-car-experience (accessed 13 October 2019). 
cart might indicate the origin of the train as being somewhere in the middle of the country. ${ }^{17}$ The visitor is supposed to feel as if they are in an American train station in late 1941. The visitor enters the train carriage and travels toward the war, while images of the train's departure as well as scenes of rural and urban America pass by the windows. The immersion is supplemented by background sounds of the train running. While the multimedia installation simulates the rattling of the train, the museum guard plays the conductor. The visitor sits on train benches and the backrests in front of them contain a small monitor. When the train experience was installed in 2014, the visitor could listen to five stories of ordinary Americans joining the five different US forces service branches, while seeing photo-album-like scenes of each narrative on the small monitors. Since the museum opened its "Campaigns of Courage" Pavilion in 2015, it has started to explain the use of the Dog Tag Experience to the visitors through the small monitors and a loud narrator's voice. This experience interactively connects each visitor with an individual narrative of the war through the use of digitally enabled IDs. ${ }^{18}$ The screens mostly explain how the Dog Tag Experience functions and the visitor can choose an identity while traveling on the train. Most visitors seem focused on understanding this procedure, which reduces the immersive nature of the train ride. At the end, everybody leaves the train to fight a just war. The experiential strategy of the museum leads the visitor to identify with one collective American voice: fighting for the 'good.' The visitor, though different from the individual soldiers featured, nonetheless becomes part of the collective journey. This overall perspective is strengthened by a variety of roles and voices that allow the visitor to fully identify with the master narrative of the heroic war to free the world. In contrast, the Dog Tag Experience allows for individual identification or empathy with one specific role.

The museum's multimedia signature piece Beyond All Boundaries: a 4D Journey through the War that Changed the World immerses the visitor in a clearly constructed and thereby secondary experiential world of the past. However, it is geared toward understanding and feeling the collective emotions of the primary historical world (see also Jaeger 2017b, 168). The New Orleans WWII Museum allows the viewer to experience what is at stake, while didactically controlling its message that the war was good, both for freedom and humanity, and that it was shaped by courage, sacrifice, and loss. The 4D film produced, directed, and narrated by Tom Hanks opened in the Solomon Victory Theater in 2009. The posters

17 The inscription was adjusted since its introduction in 2014 (based on a visit in May 2017) from Pullman to Union Pacific with the addition of the place inscription.

18 See also chapter 7 for further discussion of the effects of the Dog Tag Experience regarding the museum's depiction of the Holocaust. 
outside of the theater already begin to highlight the pathos and emotional energy of the experience through iconic texts such as "December 7, 1941 - a day that will live in infamy," "Another bulletin, Japan surrenders ... I repeat Japan surrenders," and the slogan "The war that changed the world." The narrative introduces the visitor to the main events of the war from an American perspective with an eight-minute introduction, followed by thirty-six minutes of footage covering Pearl Harbor to VJ-Day. In the pre-theater screening, the visitor is confronted with eight screens simultaneously depicting the same image or corresponding images in sets of two or four. After the show begins, it first displays statistics about the dead from the war's major participating nations, which highlights the message that the Second World War superseded all individual experiences. Following this, narrator Tom Hanks introduces the narrative that an unprepared America wanted to stay out of the war despite threats from the emerging dictatorships in Japan, Germany, and Italy. The visitor is then pictorially immersed in images of America in the 1930s, touching on themes such as the racial and religious discrimination in that era. The film then sequentially introduces the racial ideologies of totalitarian Germany and Japan, various wartime events spanning from the Japanese invasion of China and the early days of the Second World War in Europe, up until the German invasion of the Soviet Union. The picture screens are extremely effective in stirring emotions and creating pictorial impressions. This is exemplified when the viewer sees eight Adolf Hitlers simultaneously giving a speech or is confronted with eight shots of the iconic photograph depicting a child in a newsboy's cap raising his arms in surrender during a roundup of Warsaw Jews. In this way, the viewer is argumentatively and emotionally prepared for the narrative that America needs to act morally and defend freedom around the world. ${ }^{19}$

The movie theater engages four of the visitor's senses: their audio-visual senses through the use of loud noise, music, original voices, flashing lights, etc.; their sense of smell through the deployment of a sudden fog; and their tactile senses through the use of vibrating seats during a number of scenes, such as the dropping of nuclear bombs, or the first American deployment in northwest Africa. Three-dimensional objects such as a watchtower from a German concentration camp appear to grow out of the stage; the visitor seems to be directly involved in the action of flying bombers against Germany and Japan. The voice of

19 Interestingly, nowhere does the New Orleans WWII Museum ask what the Americans joining the war only following the Attack on Pearl Harbor means for the moral imperative of fighting against tyranny. Furthermore, the narrative uses the emotional argument that the American mainland was under threat as a supporting reason without ever reflecting on how realistic that assumption is. 
Tom Hanks, full of pathos, narrates a series of events, supported by propagandistic voices from governments on both sides and voices from Americans' letters and diaries, particularly those of veterans and two war correspondents. The illusion of simulated reality remains constant throughout. Every line in the show works toward emotionalizing the visitor in 'hot-media style' (McLuhan 1965 [1964], 22-23), with the message that American soldiers "saved humanity from the darkest of futures" via sacrifice and courage with their "blood, tears, and innocence," a "struggle for freedom that took them and the world beyond all boundaries." 20 The film relies on superlatives such as the largest war "in all of human history." The film constantly builds up dramatic tension with statements such as "If D-Day fails, there is no alternative." Several times, the narrator highlights that this was a new kind of war and draws connections to its global scope and the need to develop unimaginable weapons, using documentary voices to support its rhetoric. ${ }^{21} \mathrm{~A}$ moving globe helps the audience to understand the shifts between the different theaters of war and the home front. The war also becomes the vehicle by which racial and gender discrimination in the United States are overcome, particularly on the home front. A woman says: "Let's look this matter of prejudice straight in the eye. Either we are believers in the principles of democracy, or we are a collection of the greatest frauds the world has ever seen." Thus, each obstacle must and will be overcome, which in turn further confirms the master narrative.

The same goes for the description of the enemies who are exclusively racial tyrants: the installation blends out any shades of good and evil. The Eastern Front only comes into play at the end of the war. Hanks's voice briefly mentions the panicking and fleeing of German civilians, before he shifts to justifying the civilian casualties of the Air War. ${ }^{22}$ To reflect upon the cost of war, Beyond all Boundaries uses some very successful installations, such as when it highlights the human cost of war. The narrator calls the Western Union telegrams "the nation's new currency of grief," which is followed by the reenacted voices of mothers, overlapping as they read the news of their sons' deaths; at the same time images of telegrams are projected onto the stage. The war's human costs touched upon in the show are fit into its narrative: a fighter pilot describes how terrible the Air War against Germany was, but sees it as necessary; the use of nuclear

20 This is the concluding line by the narrator.

21 Such vocabulary cries for differentiation or at least comparative contextualization, since the Germans used the same word, particularly concerning their war of annihilation in the East. See also the discussion of the concept of 'total war' in chapter 8 .

22 See also chapter 8 for a more a more detailed analysis of the Air War in the New Orleans WWII Museum. 
bombs must not be questioned since they saved countless American lives; celebratory American parades and cheering follow. The 4D-visualization manipulates the viewer into forgetting the constructedness of the narrative. The atmosphere of the fighting and of the collective American emotions is authentically staged in a way that can make the viewer believe this constructed narrative represents historical reality. The story of democracy in the United States being somehow unprepared for war is told without nuance. Therefore, it cannot go beyond the war's historical era and consequently cannot represent the war's aftermath or further perspectives on the war. ${ }^{23}$ There is no room for different narratives or for visitors to find their own interpretations or to understand the narrative's constructedness. Consequently, the installation can easily overwhelm the senses of many visitors (Jaeger 2017b, 168), making it so that they share in a collective, authentic experience that confirms the political status quo of the show's master narrative. There is no attempt toward "active memory work" (Crane 1997, 63) or a dynamic collaboration between history and memory. Instead, the success of the museum and film ${ }^{24}$ is based on emotionalizing the single existing master narrative they present, which reaffirms the moral message of the war and American collective memory. ${ }^{25}$ There is no real difference between American wartime propaganda and the twenty-first-century narrator in this museum. In other words, its interpretation of the Second World War is timeless.

Beyond All Boundaries differentiates itself from other installations in this museum by not simply constructing one collective American perspective or drawing connections to a singular oral witness. In the pre-story and at the beginning of Beyond all Boundaries, the installation seems to create the collective gaze of the whole American public. It purports a narrative argument through a directly emotionalized pseudo-experience of the war. Afterwards, it shifts to the per-

23 As a minor exception, the Dog Tag Experience stations also tell the biographical story before and after the war / legacy for each featured eyewitness.

24 Generally for such techniques of emotionalization see Apor 2014; Thiemeyer 2010a, 224. The current CEO of the museum, Stephen Watson, highlights in a historynet interview how Tom Hanks's name and the idea of a film that gives "a dramatic, broad overview of the war in a very personal and engaging way" has drawn an audience that may not otherwise have come to a military history museum (Swick 2015).

25 However, collective memory cannot simply be ignored. Susan Crane has shown with the example of the Enola Gay exhibition in the Smithsonian's National Air and Space Museum in Washington, DC, how ignoring existing personal memories of powerful interest groups, such as war veterans, can risk the educational goals of historians: "Historically conscious individuals may turn out to be quite interested in the study of historical consciousness, but it will take time and patience on the part of historians and a willingness to engage personal memories in the production of history" $(1997,63)$. 
spective of Americans volunteering collectively to fight in the war, before simulating a soldiers' perspective in the Guadalcanal and northwest Africa. Whereas these perspectives persist throughout, some of the audio-visual installations seem to express different ones. The planes over Germany seem to bomb the viewers (although the viewer is in the three-dimensional cockpit during the firebombing of Tokyo), as if they were German civilians. The sounds and flashes when the concentration camp tower grows out of the ground are more reminiscent of being inside of a concentration camp, rather than discovering the camp as a liberator. The shock of the atomic bomb is experienced directly through a flash and shaking seats. However, because of the strong moral framework, these things do not allow the viewer to consider what is was like to be in a concentration camp or to experience a firestorm. Instead, these elements underline the war's seriousness and the argument that it had to be fought and won at all costs. Consequently, the multimedia installation still produces primary experientiality in the sense that it immerses the visitor into a single narrative of the war, as if it were the only existing reality of wartime. Here, however, the New Orleans WWII Museum is closer to the restricted experientiality produced in the Warsaw Rising Museum, while in most of its other parts the museum allows for primary experientiality through the interplay of collective and individual gazes. In this way, visitors feel like they can immerse themselves in a variety of perspectives, even if the museum's overarching interpretation of the Second World War remains indisputable.

\subsection{The Oskar Schindler’s Enamel Factory in Kraków}

The permanent exhibition Kraków under Nazi Occupation 1939-1945 in Oskar Schindler's Enamel Factory (Deutsche Emailwarenfabrik, OSF) opened on June 10, $2010 .{ }^{26}$ It covers 1,600 square meters in twenty-eight sections, over three levels. As in the case of the Warsaw Rising Museum, the OSF can be described as a narrative museum (Heinemann 2015, 260 -261). It is mainly a hybrid of a historical and a memorial museum that takes a strong experiential approach to "building up an 'emotional' history of the city" and permitting "certain identification of the visitors with the city" (Bednarek 2011, 37). To generate such emotional engagement, stage designer Michał Urban and theater director Łukasz Czuj created

26 The museum belongs to the historical museums of Krakow (Muzeum Historyczne Miasta Krakowa). In 2013, it received about 270,000 visitors (Kruczek 2015, 51). See also Heinemann (2015, 255 - 263) for the genesis of the 2010 exhibition. I am grateful to the leading curator, Monika Bednarek for explaining the original concept of the OSF to me, in a meeting on December 11, 2013. 
a theatrical set; ${ }^{27}$ it makes it seem like the visitor is time traveling through the years and through different scenes within a cinematic narrative (see also Korzeniewski 2016, 120). The exhibition does not give a clear interpretation or ideology of how to read the past, so that the time-traveling visitor can and must make active interpretative decisions about the past space in which they are immersing themselves in. The exhibition mimetically simulates actual historical spaces and experiences and in doing so fulfills the criteria of primary experientiality. However, its dominating tendency toward the theatrical also allows its visitors to distance themselves from primary immersion. Consequently, the exhibition displays signs of a simulated structural past, making it to some extent a hybrid of primary and secondary experientiality.

This museum uses cinematic and theatrical techniques to design its exhibition, which indirectly references Steven Spielberg's Hollywood production Schindler's List (2003); it was this film that made the building, the German entrepreneur Oskar Schindler, and the Polish Jews who worked for and were saved by Schindler, famous. The film was partially shot at the actual factory in 1993. Shortly after, it became a site for memory tourism although it remained a functioning electronic equipment factory up until 2005 (Bednarek 2011, 36). The exhibition attempts to represent the six-year Nazi occupation of Kraków from the perspectives of its citizens, while allowing identification with both ethnic Poles and Kraków’s Polish-Jewish citizens (Heinemann 2015, 267-271). In her analysis of visitor reactions in the OSF, Małgorzata Bogunia-Borowska also notes the exhibition's technique to trigger personalization and identification with the past: "The subjective engagement of emotions as well as building relations with representatives of the past make visitors more sensitive to individualized stories and to the tragedy of the times in which they lived" $(2016,249)$. The exhibition offers neither a meta-reflection of its narrative method, nor perspectives from outside the six historical years it represents. The visitor walks through narrow, corridor-like exhibition rooms, each organized according to a theme and generally following the timeline of the war. Consequently, the exhibition's narrative starts in Kraków before the Nazi Occupation and ends with the Red Army's liberation of the city and an epilogue. ${ }^{28}$

27 See also the exhibition's website, http://www.mhk.pl/exhibitions/krakow-under-nazi-occu pation-1939-1945, accessed 13 October 2019 (Fabryka Emalia Oskara Schindlera).

28 See Bednarek, 2011, 43 for a detailed description of the exhibition structure. Its twenty-eight sections contain twelve basic thematic parts: introduction: Krakow and its residents in the interwar period 1918-1939; the outbreak of the war and the early weeks of German occupation; the 'capital' of the General Gouvernement; terror; everyday life; railway station: wartime migrations, resettlements, displacements, deportations, escapes; the Jews; Oskar Schindler; history of the 
This depiction seems in line with Lubomír Doležel's idea of an actual historical world that the museum attempts to reconstruct in a model world (1999). Yet at the same time, the visitor can experience this historical world in a performative way. The narrative uses sound, sight, and architecture to simulate historical experience. The visitor goes, for example, through a dark, narrow, steel and concrete tunnel, wherein the outbreak of the war is represented. This room focuses particularly on the perception of sound. The visitor hears noises of fighting, radio propaganda, and the roar of air-raids. The darkness intensifies the visitor's loss of orientation during the simulated battle. To highlight the authenticity of the narrative, the room displays different pieces of Polish army weaponry in a model field bunker. Regular panels and a computer station supplement these objects in order to fulfill an informational function.

At first glance, the exhibition works with a very similar technique to that of the New Orleans WWII Museum in constructing primary experientiality. As in the "Road to Berlin" and "Road to Tokyo" exhibitions, the Kraków museum creates stage scenes that allow the visitor to empathize with the collective gaze of the citizens of Kraków. Visitors listen to the cries and sounds from prison cells, highlighting the beginning of the deportation and murder of Kraków's Jews; they then enter the central railway station, experience the establishment and destruction of the Kraków Ghetto, and walk through a set of the Płaszów concentration camp. A closer analysis reveals, however, that this collective perspective is less unified than in the New Orleans WWII Museum: the exhibition simulates the collective perspectives of Kraków's ordinary citizens - both Polish and Jewish as a new "We"-community (Heinemann 2017, 252; 2015, 271) - including the Polish soldier, the German occupiers (albeit in a very limited way), the Jewish inhabitants of the city during their deportations and life in the ghetto, the Polish members of the underground, the inmates of Płaszów concentration camp, the Catholic Church, and children and women, among others. ${ }^{29}$

Despite its theatrical setting, which is potentially manipulative of visitor emotions, the OSF also avoids the strong moral coding seen in the New Orleans WWII Museum. Rather, it uses a documentary style, which leaves room for the interpretation of the historical data and artifacts on display - images, objects, voices, and theatrical installation can affect the visitor. Indirectly, this technique still codes the exhibition, as it has a clear-cut black-and-white pattern. Germans,

DEF and its workers; the Polish Underground State and its structures in Kraków; the Plaszów camp; the last months of the occupation; and an epilogue: the "Hall of Choices."

29 See also Guichard-Marneur 2018 for a narratological reading of the museum space, even if it seems a stretch to read the museum as an mere expression of Polish victimhood that particularly points to the 'Communist occupation' until 1989. 
including the Nazi occupiers, the newcomers to the city, and the ethnic Germans who lived in Kraków before 1939, never function as collective focalizers. Crimes are explicitly perpetrated by means of German agency. The last room entitled "Hall of Choices" is an exception to this rule, although it also clearly codes good and evil, right and wrong. Thus, the museum ends in explicit moral coding, in contrast to the open-experiential style of the rest of the exhibition (see also Heinemann 2015, 275-277; Heinemann 2017, 259-267). The scenes in each room represent spaces in Kraków before and during the occupation. Yet their setting and the exhibits used throughout, particularly photographs, are not as illustrative and functionalized as in New Orleans. The museum's representational techniques allow considerable room for interpretation.

The third difference between these two museums, which produces a different quality of experientiality, can be seen in their simulated theatrical-cinematic effects (see also Heinemann 2015, 259-260). In New Orleans, the visitors move with American soldiers from one battleground to the next, as if they were also soldiers. In Kraków, visitors become a ghostly presence in a historical space, observing the realities of the city. They are not specifically Polish, Jewish, or German, but are immersed in the simulation of a time traveler walking through a film set. ${ }^{30}$ The visitor moves through narrow, corridor-like exhibition rooms, each organized according to theme and generally following the timeline of the war. The museum uses calendar sheets and street signs to give visitors an exact orientation of where they are moving in time and space. On the one hand, this forces visitors to move in a linear fashion as if they were watching a film (Jaeger 2015a, 153). On the other hand, the visitor can experience each scene from a cinematic perspective, so that the history of Kraków during the occupation comes to life in a performative way. ${ }^{31}$ The exhibition employs a combination of modern museum didactics, technology, and theater-derived techniques. It targets different senses, in order to create a new, clearly poietic world that guides the visitor through this performative experience of the past. It employs sound, sight, and architecture to further simulate historical experiences. In other words, the OSF's exhibition does not simulate a collective perspective, but rather a historical space. Visitor are never under the illusion that they

30 Another museum that fits in this category is the Resistance Museum (Verzetsmuseum) in Amsterdam (1999) that recreates collective experiences and historical spaces during the German occupation. As in the exhibition in the Oskar Schindler Factory, the visitor becomes a kind of time traveler through the conditions of the occupation. Unlike for example the Warsaw Rising Museum, here resistance against occupation is portrayed less heroically.

31 See also Bal 2008, 26-35, for cinematic metaphors to describe the effects and possibilities of agency by museum visitors. 
are truly re-experiencing the past and are always aware that the simulated space is theatrical and consequently distanced from actual events. Therefore, the OSF creates spaces that immerse its visitors in primary experientiality, although its effects are a hybrid of primary and secondary experientiality.

The representation of the beginning of the occupation further demonstrates the exhibition's hybrid experientiality. The visitor enters the hallway of a Krakow apartment house on September 11, 1939 and hears "the hubbub of gossip and conversations etched with fear" (Marszałek and Bednarek 2010, 16). The hallway looks barren, the floor is made of copper stone, and the white-greyish walls look old and dirty. The visitor encounters an old water basin, a stroller, and twenty mailboxes. Four contain envelopes and postcards in Polish and German writing that, for example, tell the inhabitants of the building that their family members have become prisoners of war. Through a wooden door, the visitor moves outside 'into' the Aleja Mickiewicza. The copper stone floor transitions into a brighter color, and the visitor encounters a mass of Nazi announcements accompanied by two large red Nazi Swastika flags on the street, which one must sidestep around. The impression that Nazi propaganda is taking over the city of Krakow is re-created through this performance. The visitor experiences the evolution of Nazi orders regulating life in the city. The exhibition alludes to the fact that the visitor is an inhabitant of the city since they seem to come out of the townhouse. The corridor ends with an enlarged photograph of the Nazis hoisting a Swastika flag as symbol for the newly established Generalgouvernement supplemented by real footage. Then, the visitor steps into Kraków's famous Old Market Square and encounters photographs of German soldiers touring Kraków and humiliating Orthodox Jews by shaving their beards.

A quotation by Julian Waga (presumably a Polish citizen, though the exhibition does not contextualize him) further shapes the impression one gets of the mood in Kraków: "What is left of the high-sounding and expressive words about our power [...] and the moment of lightning defeat is immense ... We walk around in a daze, still unable to admit to ourselves that this is the beginning of a catastrophe we have not seen in our history." A large wall poster that acts as the background to the photographs and texts shows a menacing looking German soldier in the foreground with people passing behind him through the street with flags. Thus, visitors are emotionally prepared to take the side of the Polish and Jewish citizens of Kraków and immerse themselves into the oppressive atmosphere of the occupation. The next exhibit, a façade and the front display window of Heinrich Hoffmann's bookstore opening onto the market square, reinforces this notion. The bookstore's display is symbolic for the beginning of the Germanization of Kraków. Next to it is an excerpt of a German radio interview with Heinrich Hoffmann, one of the few German primary voices in the exhibition. Hoffmann describes the 
liberation of Kraków's Volksdeutsche (ethnic Germans) and how they purchased the Führer's portraits: "Now, enabled to purchase the longed-for likeness of the Führer, they finally feel free. We considered it our principal duty to provide these people with such possibility." He also comments on the constant changing of the items and pictures on display "to show the Poles what our Führer is like!” Of course, the museum visitor is in no danger of identifying with Hoffmann's voice. The exhibition does not focalize ethnic Germans; German quotations are either propaganda or horrific quotations by Nazi leaders. At the end of the exhibit, the visitor can see the outside of a tramcar with the sign "Benutzung für Juden verboten" (use forbidden for Jews). Throughout the exhibition, photographs - at times enlarged to poster-size - play a significant role in capturing the historical atmosphere. In the section "City Square 1," as analyzed above, the OSF creates a very specific experiential effect. Throughout the announcement and flag corridor and the market square, the museum simulates the destructive force of the occupiers. Although the museum does not directly interpret the material itself, the moral interpretation of the section is clear.

The exhibition constantly switches between exterior and interior spaces and indicates these transitions through the setting, particularly the flooring. Moving on from the city square, visitors enter a room that is set to replicate Lecture Hall No. 56 in the Collegium Novum of the Jagiellonian University. It is here that they can hear the original German speech made by Gestapo officer Bruno Müller, regarding the arrest of university professors on November 6, 1939. Visitors become witnesses to the infamous 'Sonderaktion Krakau' and can feel the shock of Kraków's citizens. They travel on a timeline through space, i.e. the unfolding of the historical word depends on the visitor's presence. This is performative in the sense that, on the one hand, it references a historical world; on the other hand, it creates a historical space, as if the visitor is traveling through the past.

The exhibition then switches to the outside in the section "Generalgouvernement," in which the exhibition comes closest to creating the perspective of the German occupiers. The calendar sheet makes note of November 7, 1945, the day when governor Hans Frank moved into the Wawel Castle. The room is extremely bright with white background, walls, and ceilings. The floor consists of white tiles with black swastikas, and the visitor circumvents two advertising pillars each displaying an enlarged photograph of life-sized German soldiers marching and saluting (see fig. 10). The sounds of military marches fill the room. Throughout the room, the exhibition stages the feeling that the public side of Kraków is becoming increasingly Germanized. This is communicated though street signs, official cultural events that are symbolized on a third advertising pillar, and a display of the Nazi's architectural plans for redesigning the city. Although a period-appropriate wooden advertising board introduces the 


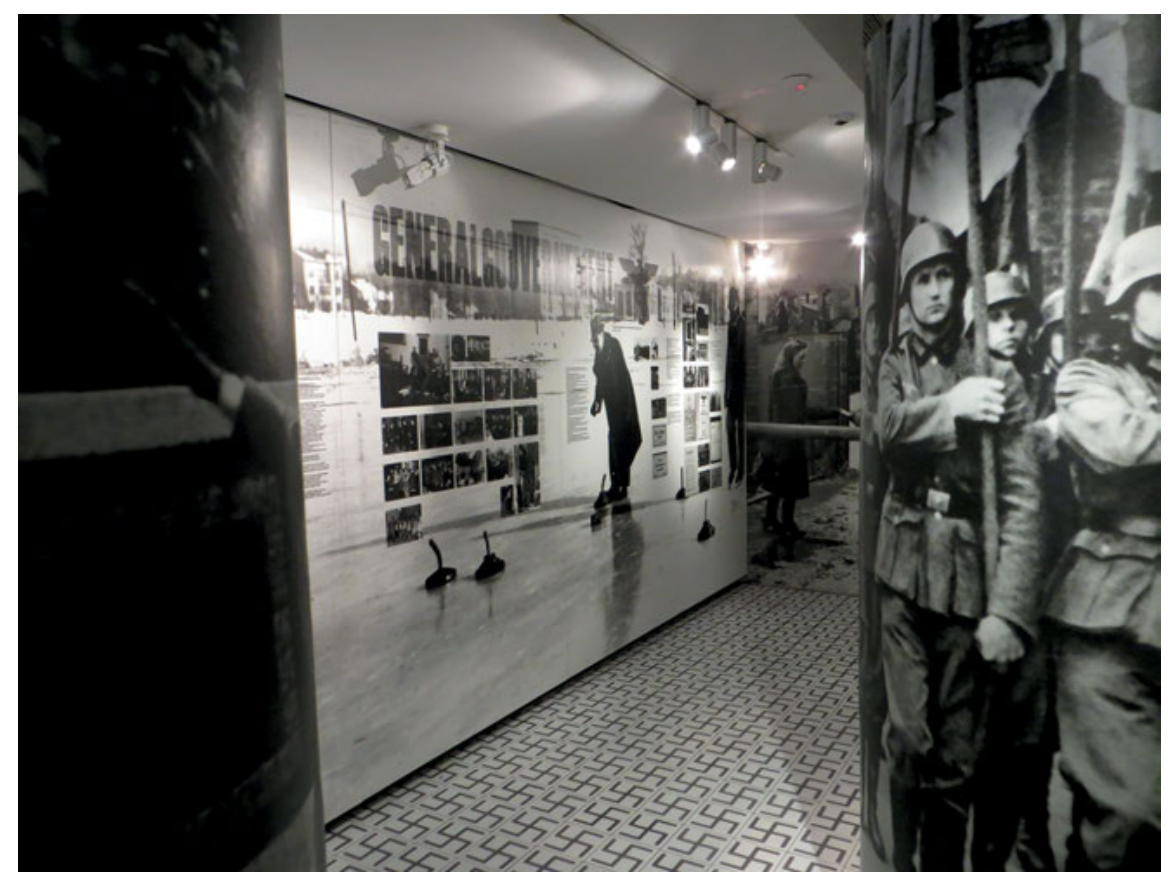

Fig. 10 Section “Generalgouvernement." Permanent exhibition. Fabryka Emalia Oskara Schindlera, Kraków (Photo: Author, 2013, courtesy of Fabryka Emalia Oskara Schindlera).

role of Volksdeutsche and contrasts it to that of the superior Germans, neither the perspectives of the Germans nor the Volksdeutsche are expressed in the exhibition. Instead, they are presented through photographs and other descriptive materials, while the German individual remains anonymous. At the beginning of the room, the museum stages it to seem like visitors are present at Frank's triumphal inauguration. As they are forced to walk on swastika tiles and must circumvent the pillars of soldiers, the exhibition creates feelings of alienation in the visitor at this foreign intrusion. Whereas museums normally keep a distance from the enemy, here visitors enter in close proximity with the Nazis staging their political power. The theatricality of the approach is cognitively clear to the visitor, and because of this there is no danger of being seduced by the Nazi propaganda. Although the visitor is immersed in the emotional effects of foreign intrusion, the exhibition also offers plenty of room for interpretation. For example, on the wall are two signs in German "Für SS und Polizei verboten" (prohibited for SS and police) and "Für die Wehrmacht verboten" (prohibited for Wehrmacht members), used by some restaurants in Kraków to deny admittance to members of the SS, Gestapo, and Wehrmacht. While these clearly indicate that there was 
public resistance, their meaning beyond this is open. Was it a common form of resistance? How did the Germans react? Was it sustainable? The signs open up a space for further interpretation of how one can and should live during a period of occupation.

This double technique that uses, on the one hand, clear and partial perspectives affecting the visitor's sympathies and on the other a more open documentary approach, is visible throughout the whole exhibition. As mentioned above, ${ }^{32}$ when visitors enter Kraków's famous Old Market Square in 1944, they walk between transparent plexiglass panels, which are spread throughout the room and tell different stories about historical people, representing different types or groups in Kraków during this era (see fig. 11). This has the potential effect of making visitors like they are encountering these people in their roles in Kraków's main market square as well as their everyday life. For example, one plexiglass panel shows four middle-aged women holding hands and smiling. This text describes how these women's husbands were soldiers that were imprisoned, leaving the women to find their own means of survival: "The occupation forced them to alter their behavior. They became self-reliant and resourceful." Although the OSF avoids naming these individuals, the visitor can empathize with their situation and actions. This is in strong contrast to the indoctrination by Swastika flags and marching anonymous masses seen in the sections "City Square I" and "General Gouvernement." Another example of this is the first section charting everyday life during the occupation " 1940 - 41.” Here, the visitor can enter a tram cart on the Salvator line, which was established exclusively for German use. This means visitors undergoes a degree of empathetic unsettlement, as sitting down on a seat and watching German propaganda films through the windows of the tram places them in the Germans' position.

My last example of how the exhibition creates a hybrid of primary and secondary experientiality is its depiction of the Kraków ghetto. Visitors climb the stairs to the upper floor and the Planty Garden Ring, where they can watch projected German newsreels. From these bright leisurely scenes, the visitor enters a dark corridor of the ghetto. At first it seems like the visitor is seeing the ghetto from the outside before entering it. Integrated in the wall are photographs of its streets and residents as well as quotations from firsthand accounts about life in the ghetto. In between two parts of the Ghetto wall, there are two reconstructed rooms, symbolizing the extremely overpopulated conditions and the fact that strangers were frequently housed together (Marszałek and Bednarek 2010, 30). The interior diorama shows mannequins made completely of white

32 See also chapter 2.2. 


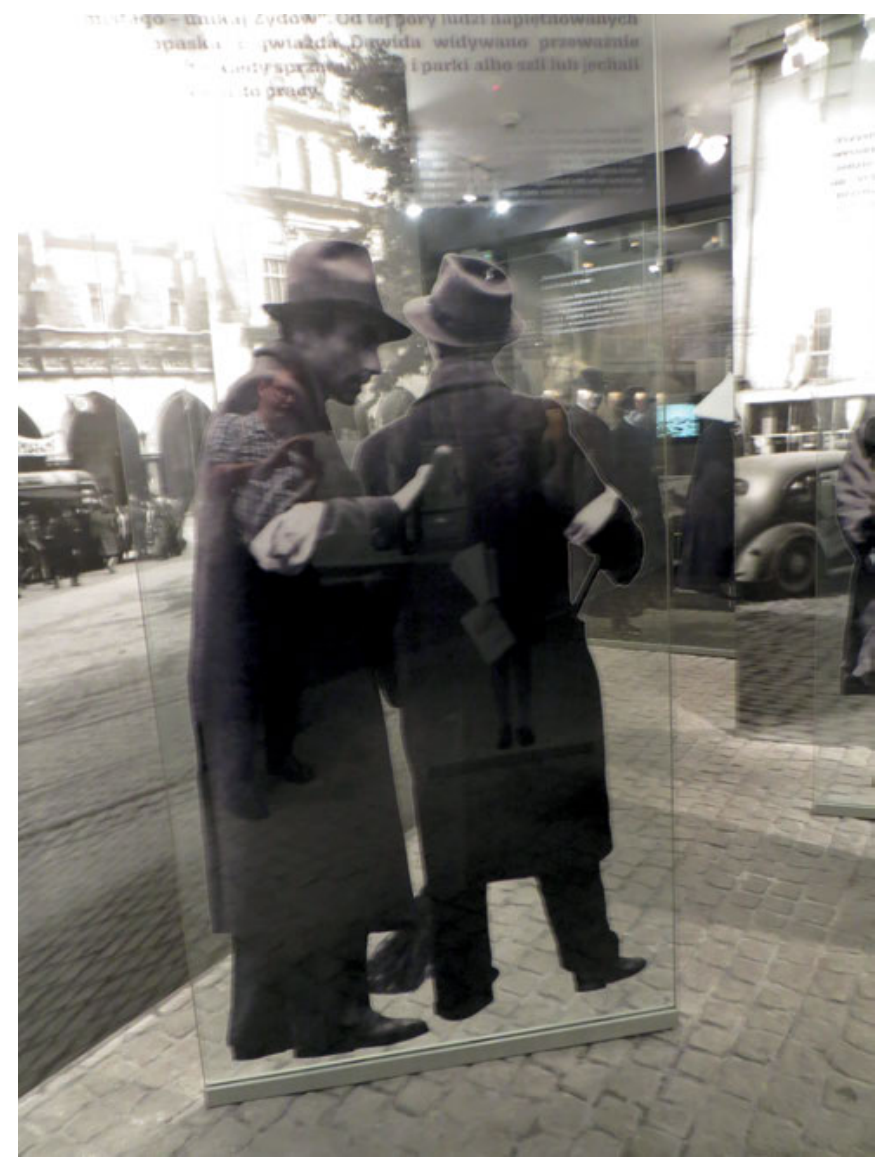

Fig. 11 Meeting historical people in transparent plexiglass panels in Kraków's Old Market Square in 1944. Permanent exhibition. Fabryka Emalia Oskara Schindlera, Kraków (Photo: Author, 2013, courtesy of Fabryka Emalia Oskara Schindlera).

plaster, creating a gap between this representation and the people represented. In other words, although this model ghetto imitates the primary experience of the historical one and thereby impacts the visitor emotionally, visitors never lose the feeling that they are time travelers in space who are unsure of whether they have the right to see what they are viewing. The act of looking at this interior scene is more about the feelings of awkwardness created by gazing into somebody's private space than about the reconstruction of that space. This distances visitors and leads them to the meta-reflection about how immersing themselves in the past is cognitively and ethically possible, leading to effects of secondary experientiality. 


\subsection{The Bastogne War Museum}

As seen in the Oskar Schindler Factory, the permanent exhibition in the Bastogne War Museum: Living Memory of the Ardennes (BWM) is a hybrid between primary and secondary experientiality. Both museums employ their local subject matter to create immersive experiences. The BWM, however, establishes considerably more of a historical structure and employs a larger variety of distantiation to counterbalance its immersive and empathetic techniques. The museum opened on March 22, 2014 and is located in a new building, ${ }^{33}$ next to the Mardasson Memorial honoring the American liberators. The mission statement places emphasis on historical tourism: "The point is to turn the 'memorial tourism,' of which the memorial fact is less and less present in the collective memory, into a 'history tourism' with a clear civil and educational calling." 34 The fact that the museum is more interested in tourism than in historiographical research is evident. For example, it only uses an English name, even on its French- and Flemish-language websites. The museum's website also still clearly defines it as a memorial museum by attributing the word "memorial center" to the institution on its entry page. ${ }^{35}$ For a local museum on the theme of a specific battle located far away from larger population centers, it is quite successful at about 150,000 visitors per year, almost half of which are international. ${ }^{36}$ The museum's exhibition relies on numerous audio-visual features, including image collages, enlarged poster-like photographs, video eyewitness accounts, floor and wall design, and display panels that constantly change color. The museum uses original objects, but they are secondary to the exhibition's visual and experiential approach. The anchor points of the permanent exhibition are three scenovisions, three-dimensional theaters where the visitor enters a stage in order to be immersed in the events of the war. The museum was designed and is managed by the Belgian company Tempora. The new building and exhibition was financed by local and regional tourism funds and the European Union. ${ }^{37}$ The architecture of the bunker-like building is nestled into its surroundings by the Atelier de l'Arbre d'Or to disorient the visitor, similar to Libeskind's architecture in the Bundes-

33 It replaced the Bastogne Historical Center, which was more of a traditional military history exhibition with weapons and memorabilia commemorating the battle. The Bastogne Historical Center was closed in 2009.

34 Bastogne War Museum 2014, 11.

35 https://www.bastognewarmuseum.be/en/home-en/, accessed 13 October 2019.

36 At least in first two years after opening, see Bastogne War Museum, "Press Release-May 2016,” http://www.bastognewarmuseum.be/press-kit.html, accessed 9 August 2018.

37 Bastogne War Museum 2014, 38. 
wehr Military History Museum and in the Imperial War Museum North: "Creating spaces outside their axe [sic], lead-free materials, and the unbalance in the plans constantly create new points of view, which leave the visitor with a feeling of surprise and disorientation." 38

The BWM has one of the most original approaches in terms of museums representing the Second World War, with its simulation of war experientiality centering on fictitious characters. ${ }^{39}$ The permanent exhibition is situated on two levels. ${ }^{40}$ The ground floor is structured as follows: it starts with "Before the Battle of Bulge" with the segments "From War to War" (three rooms including the first scenovision), followed by "Belgium in the War" (one room) and "Towards Liberation" (four rooms with the last focusing on the German preparations for the surprise counter attack). In the basement the visitor encounters the "Battle of the Bulge" (about five sections, including two scenovisions ${ }^{41}$ ) and the aftermath of the Battle of Bulge with four sections covering the Allied victory in Bastogne and in the overall war, Belgium at the end of the war, and an epilogue). The ways in which the BWM frames the 'before' and 'after' the Battle of the Bulge allows it to exhibit a close-up display of the battle, while simultaneously narrating certain national and global layers of the war. Through the audio-guide, visitors automatically hear the narrative voices of four fictitious characters: Émile, a 13-year-old student, Mathilde, a 25-year-old teacher and casual member of the Belgian resistance, Hans, a 21-year-old Wehrmacht Lieutenant, and Robert, a 20-year-old American soldier of the 101st Airborne Division (see fig. 12). All four characters are visualized as figures from a graphic novel; as soon as visitors approach an illustration of the upper part of the characters' face highlighting their eyes on the walls throughout the museum, they can listen to the relevant part of the character's audio story.

The characters are constructed as composites from many eyewitness accounts of the battle from American, German, and civilian perspectives. Despite their cartoon-like construction, the visitor is likely to perceive the characters

38 Bastogne War Museum 2014, 15.

39 The Gdańsk Museum of the Second World War exhibits a children's exhibition entitled Time Travel: the Story of a Family and its Home, which is centered around three rooms of the family's home that change over the course of the war. The visitor can, however, only hear the story through the audio installation in Polish and the exhibition is specifically designated for children twelve and under, so that the use of fiction is a mere didactic tool that does not influence most museum visitors (for further context, see Machcewicz 2019 [2017], 83-84).

40 For the structure of the exhibition, see also the visitor guide Bastogne War Museum 2016. 41 Since the visitor follows a sequence with the option of skipping the second and third scenovision, what exactly makes up a room is arguable, especially concerning the corridor-like sections. 


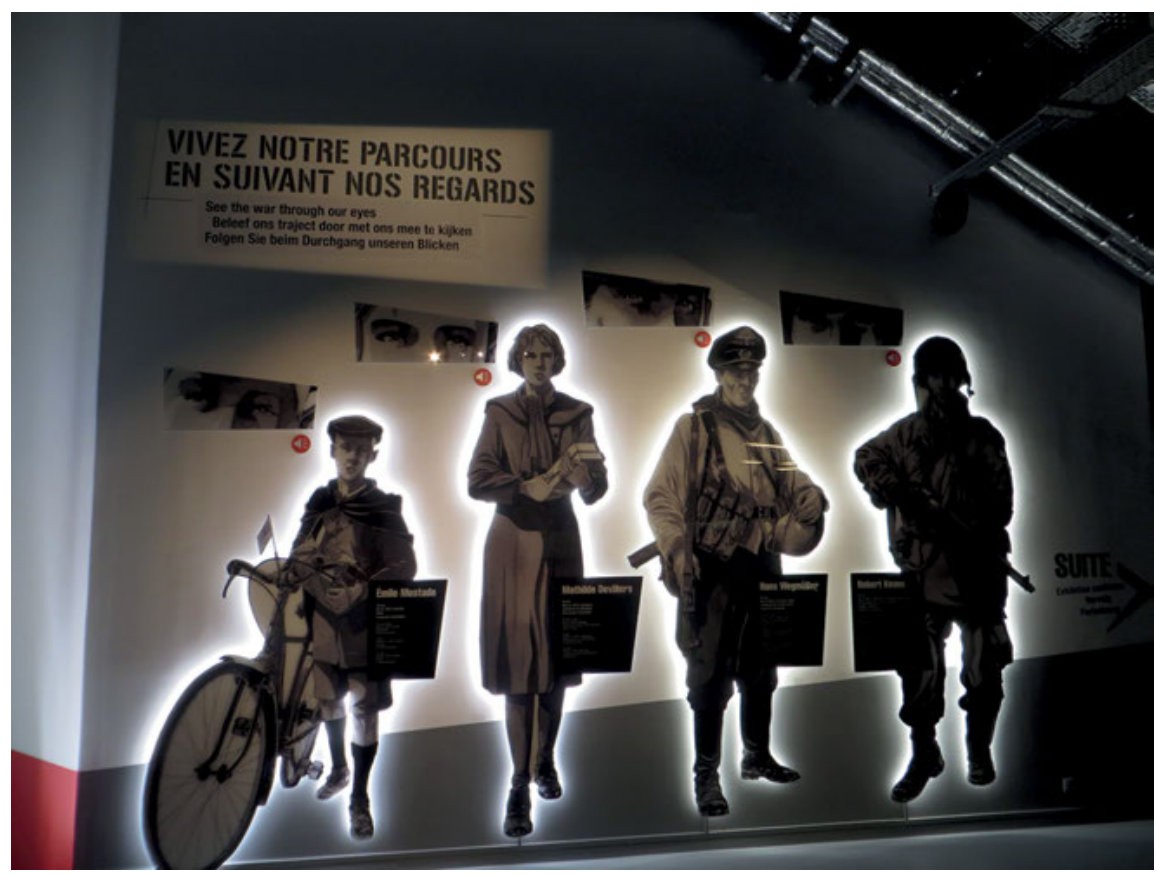

Fig. 12 Narrative characters "See the War through our Eyes." Permanent exhibition. Bastogne War Museum, Bastogne (Photo: Author, 2016, (C Bastogne War Museum).

as real historical figures. ${ }^{42}$ In the exhibition's last section depicting the end of the war, the audio tour ends with the story of all four characters - as if they had lived through the Battle of Bulge - and describes their fate afterwards. In this way, each character is given a typical fate that many endured after the war. Robert, whose brother John died in the Pacific, takes over his parent's shop, has three children, but loses his oldest son in Vietnam. "Wars have caused me so much pain." He returns to Bastogne and the Mardasson memorial with the veterans of the 101st Airborne Division. Hans, originally from Frankfurt Oder in the East, relocates to West Germany in order to get involved in politics alongside Chancellor Konrad Adenauer. "I participated in the reconstruction of my country and Europe so that a war within its borders would never again be possible."

The BWM tries to display the characters' inner tensions, such as the tension faced by Robert after the death of his brother between mourning and the heroism

42 The museum catalog - unlike the exhibition itself - clearly marks that they are "fictitious witnesses" but notes that they are also "very real all the same” (Bastogne War Museum 2016, 81). 
of his own participation in the war. Despite this, the visitor still experiences fairly stereotypical characters. For example, Hans's story confirms the superiority of Western freedom over the East without challenging possible problems in the West, such as the lack of post-war De-Nazification. The emotional attachment that the exhibition fosters between the visitor and these fictitious individuals, who function as composite models representing possible types of people in specific groups, downplays the multiplicity of options and personal reasons behind different behaviors during and after the war.

The visitor listens to these characters from an up-close perspective, mostly as people who directly experienced the battle, encirclement, and bombardment of Bastogne. Sometimes, however, the characters provide larger contexts from a greater narrative distance. This especially holds true on the upper floor of the exhibition and in the first scenovision, which intersperses an overview of the war from 1939 to the eve of D-Day with concrete accounts by all four characters, framed as a fictitious pre-D-Day press conference. Occasionally a separate narrator touches on certain events of the war that the exhibition cannot directly link to the characters. This corresponds to the exhibition's technique of constant variation between proximity and distance. The visitor is often very close to the characters. For example, when Mathilde joins the resistance her disdain for collaborators and enthusiasm for the resistance is evident, as is Émile's contempt for the German occupiers. Yet Mathilde also expresses fear for her family members in the possible case of her arrest, displaying the potential reasoning behind the collaboration of others. Mathilde and occasionally Émile are also responsible for providing a survey of the political situation in Belgium.

An example of a more distant perspective can be found in the second room, "From War to War," in which both Hans and Robert tell the visitor about their parents and the economic challenges they faced in the 1920s and 1930s. ${ }^{43}$ Hans's story is particularly interesting; on the one hand, he tells a story that he has heard secondhand, as he was born in 1923 and therefore too young to experience it himself. Thus, everything he reports comes from others and mainly his father, who fits the classical stereotype of a German worker following Hitler. He blames the Allies and especially the Jews, who he claims had been involved in financial speculation, for the economic crisis. Hans concludes that, from the perspective of the ordinary people, Adolf Hitler seemed to be "the only solution" as well as "the only person to defeat Soviet Bolshevism." The story shifts in proximity: it relates to the characters' real experiences and their feelings in concrete

43 In June 2018, two out of three audio signals in room two did not work and were marked as out of order, significantly reducing the effect of the characters' biographical backgrounds. 
situations; it also features a further distance when the characters almost seem to be giving a historical overview on the political, military, or economic situation; as well as a middle distance, where the characters narrate one possible story, which simultaneously incorporates the stories and stereotypes of millions of people during this era. Through this narrative style, the BWM is able to display how immersed a particular character is in his surroundings.

Hans reacts to the historical events and cheers when the German army attacks and defeats Poland, ${ }^{44}$ and it follows logically that he becomes an officer indoctrinated by Nazi propaganda. At first, he is convinced that the Germans will win the war: "We are going to bomb the English and they will understand our superiority." ${ }^{45}$ However, he later becomes disillusioned and merely acts as a responsible officer in the Battle of the Bulge and, following his imprisonment, simply as a decent human being. ${ }^{46}$ At the same time, a lot of stereotypes are mentioned in a way that could potentially allow the visitor to believe the same propaganda that influenced Hans. The display walls with photos, document facsimiles, texts, and small horizontal vitrines with illustrative objects on the walls counteract this impression by employing a documentary style. Furthermore, the rise of totalitarian regimes in Europe (Germany, Italy, Soviet Union) and German racism is clearly documented. ${ }^{47}$ Despite this, the risk remains, as the exhibition does not explicitly call the Nazi propaganda into question. This can be seen in one of the computer stations, "What would you have done?," in which visitors can click through a slideshow of texts and contextualizing photographs before they have the opportunity to choose one of four questions. This tool further runs the risk of under-contextualizing cause and effect. For example, one slideshow entitled "After the 1914-18 War," documenting the human, economic, and political legacies of war, reads on its last screen: "Right after the First World War, the bruised and exhausted victors are longing for peace." It then asks the question: "Should Germany be pun-

44 In the first scenovision.

45 First scenovision.

46 It is important to note that Hans's story is strangely quiet on his personal experiences in the East, although his first deployment occurs in December 1941 at the gates of Moscow. His character has sympathies for Nazism and Hitler, yet when it comes to real war crimes, he falls silent. Of course, one can argue that this is beyond the scope of the museum and would be the task for a fictitious composite character in a German museum.

47 The BWM always connects world events with local events in Belgium, so that visitors obtain a documentary overview of economic and political developments in Belgium, including the rising Flemish nationalism. 
ished?" The visitor receives two options: ${ }^{48}$ "Yes, to get compensation, to take revenge, or to serve as a warning." Or: "No, that could lead to the Second World War." This runs the risk that the visitor will view the Treaty of Versailles as the singular, or at least major reason for subsequent historical developments.

The second and third scenovision emotionalize the visitor through a combination of storytelling and images. They overlap in parts with the audio guide, but add important details to the story and create a consistent multiperspectival narrative. The second scenovision, entitled "The Offensive: In the Woods near Bastogne: At the Dawn of 16 December 1944...," can serve as primary example for how the exhibition creates experientiality for the visitor. Visitors sit on tree benches looking at the stage of the Bastogne Forest, which is covered in tree stumps. Machine-guns emerge out of foxholes (see fig. 13). A three-dimensional projection of visual scenes and audio immerses the visitor in the forest. The occasional wafts of fog and the smell of smoke underline this multisensory experience. The sky projected on the ceiling fills with parachutes at one point. The cartoon characters are projected as images on the wall, which breaks the visitor's illusion of reality. The voices contextualize the fighting and shift between closer and farther proximity to the battle. Although the title of the scenovision identifies a specific moment in time as its starting point, it narrates the whole German counterattack and encirclement of Bastogne through the voices of the four characters, up until the United States Third Army of General Patton relieves the 101st Airborne Division on December 26, 1944 (see also Jaeger 2019, 60 - 61).

The visitor can empathize with all four roles, although Émile's and Mathilde's roles are more prominent in the third scenovision, highlighting the civilian experience. At the beginning of the second scenovision, Hans and Robert's perspectives as soldiers quickly change. For example, Hans reports on the different villages that the Germans conquer while focusing on Bastogne. At the same time, the Americans have received reinforcements. Hans provides an idea of the general situation, describing where the German advance was halted and what areas are still under American control. He then highlights how his men raze every forest they come across. The narration then switches to Robert, who says "We have been digging foxholes all night long; we are ready for them." Explosions start and the visitor is immersed in a battle narrated from the American perspective through Robert's commands. Dramatic music overlaps with the sounds of fighting, and Hans's voice sets in, talking about the lack of success

48 Normally, the visitor receives four options. In June 2018, slightly more than four years after opening, only four out of ten of the computer stations with background information and the "What would you have done?" were still working, considerably reducing the impact of this tool. 


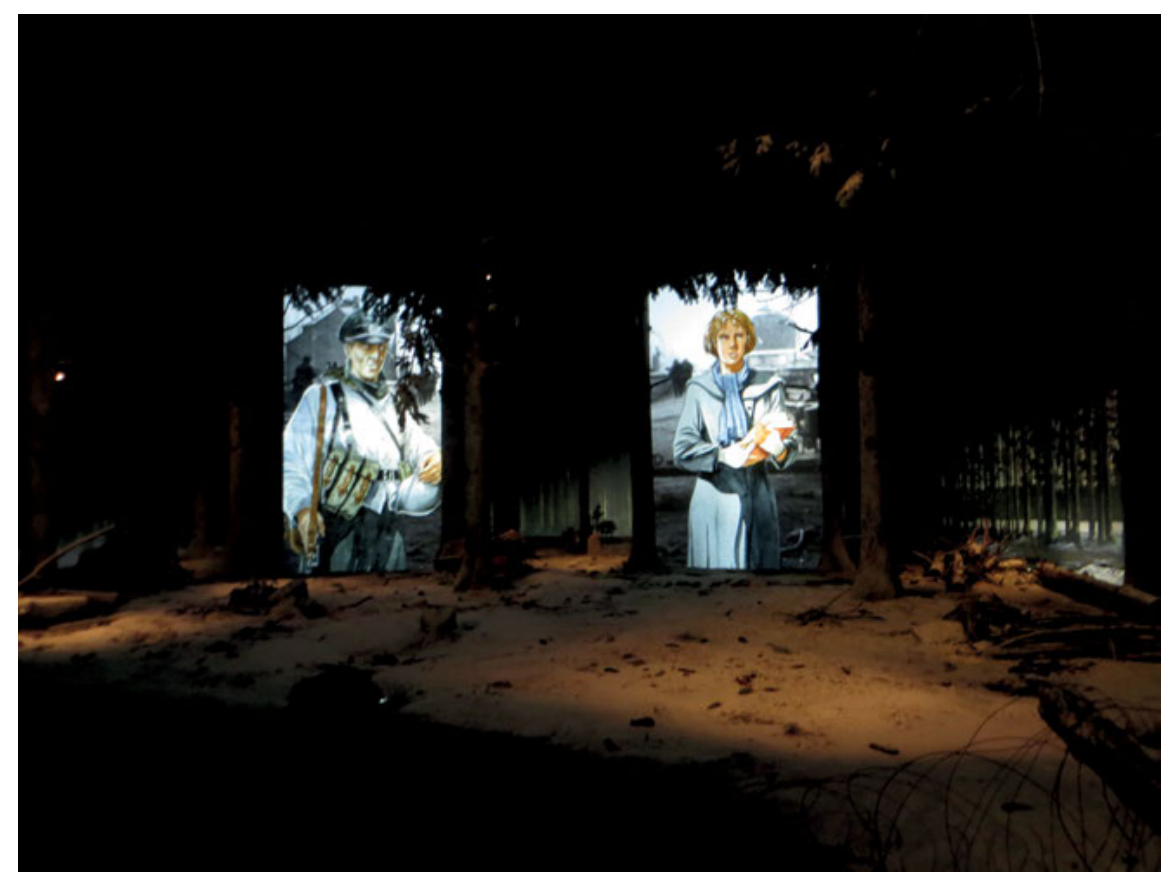

Fig. 13 Scenovision 2: "The Offensive: In the Woods near Bastogne: At the Dawn of 16 December 1944 ....” Permanent exhibition. Bastogne War Museum, Bastogne (Photo: Author, 2016, () Bastogne War Museum).

and how exhausted his men are after going for two days without real food. This back and forth between the two situations continues, highlighting the human needs of each group while providing an overview of the military situation. This goes on until Robert's group captures Hans. Iconic images, scenery, a multimedia show, and the narrative all work to authenticate each other. The visitor is emotionalized to empathize with all four characters; they are all represented in a reconciliatory way, so that no conflict between them arises. The visitor can identify just as much with Robert as with Hans because of the narrative's emphasis on their human character traits. However, this identification is continuously broken-up (see also Jaeger 2019, 60); first through the constant shift in proximity and distance to the soldiers' 'real' experiences and summaries of the battle and secondly through the multiperspectival shifts between the four characters. The visitor experiences a secondary meta-reality of the whole battle that consistently includes primary forms of identification with the perspectives of specific characters. 
This form of representation carries a conciliatory and - to an extent - antiwar message. Consequently, the visitor could potentially lose the ability to critically engage with war crimes and the soldiers' ideology. Hans seems too moral of a character despite being fascinated by Hitler at the age of $16 .{ }^{49}$ At the same time, he seems to be a prototypical German soldier. For example, he alludes to the fact that he served on the Eastern Front in Russia, but does not give any insight into what atrocities were perpetrated during the war of annihilation. However, images, interview footage, and text throughout the exhibition interweave the stories of the four characters with war crimes in the Ardennes, Belgium, and across the world as well as with the Holocaust. The museum transcends cheap empathy or simplistic entertainment experiences through a complex structure that combines iconic images, fully-developed narrative perspectives, and an empathetic experience of an authentic, but clearly constructed scene in the woods near Bastogne. This allows the visitor to develop questions about war beyond the goal of empathizing with the soldiers in the forest or with the civilians in bombed-out Bastogne cellars.

In the third scenovision, all four characters, including the prisoner of war Hans, meet in a café owned by Émile's uncle during the night of the bombardment of Bastogne by the Luftwaffe on December 23-24, 1944 (see also Jaeger 2019, 62-63). The visitor is placed to watch and listen, first in the café, then in its basement. On the one hand, this is a very intimate, if slightly unrealistic setting. The civilians share soup with Hans, who mimics playing the cello, while Robert plays his harmonica and Émile plays a waltz on his accordion in the dimly lit basement. The characters start to bond over music and talking. At the end of the scenovision, Émile hears news of his parents' death and Mathilde describes how she teaches a lesson in a post-war classroom near Bastogne by analyzing a German text, which states that the world may never see such a Christmas again: "To snatch a child from his mother, a husband from his wife, a father from his children, is this worthy of a human being? [...] Universal

49 As per his descriptions in the first scenovision and room two. However, in room ten following the second scenovision, the visitor receives a partial authentication of Hans's character through a personal video narrative. Paul-Émile Englebert, who had been taken prisoner by the Germans, remembers a two-hour conversation with an unnamed German soldier who was Catholic and around eighteen-years old from the Rhine region. This soldier told Englebert how his mother had said that he must obey, but that the war was unfair and the Germans would lose. She had asked her son to eat enough and dress warmly if needed, but leave the women and girls alone and not bring any souvenirs home. According to Englebert, the German was proud to have kept his promise to his mother. The visitor can clearly recognize some of Hans's biography and human traits in this unnamed German soldier. 
fraternity will undeniably rise from the ruins, blood, and death.” The scenovision ends with Émile riding his bicycle, accordion on his back, to the sea. It had always been Émile's dream to see the sea and ride there by bicycle with his father, the owner of a bicycle shop. The cartoon-like character Émile becomes a real person in the footage, who is seen by the viewer disappearing on a road into the distance with images of the sea. Even more than in the previous scenovision, the characters are used to reinforce the overarching message of the brutality of war. The BWM brings the everyday experience of war very close to the visitor, who can empathize with the personalized and stereotypical experiences of the different characters.

In order to understand how this primary reality does not completely overtake the visitors' emotions, it is important to further analyze other exhibition techniques in the museum. The museum highlights eyewitness accounts of civilians and soldiers who lived in the region during the war throughout the exhibition on small video screens. ${ }^{50}$ For example, the room following the third scenovision charts the aftermath of the battle in the Ardennes, two video screens display the traumas of war through interviews with three survivors who narrowly escaped the mass executions of civilians in Parfondruy and Bande. ${ }^{51}$ The eyewitnesses describe in detail how the Germans killed one civilian after another and the viewer sees the witnesses today remembering these war crimes. This whole section is dominated by the sound of funeral music. The second part of the section contains a very bright aisle consisting of seventeen gravestones of people with different nationalities who died during the Battle of the Bulge. Slideshows of photo albums are integrated into their horizontal parts. Behind both sides of the aisle are large mirrors mounted on the wall that reflect the visitor and the graves multiple times over, creating the illusion of a full graveyard landscape and immersing the visitor deeply in the scene. At the end of the opening to the next section is an enlarged photo poster of the provisional American Military Cemetery in Foy-Recogne. This gives the visitor the opportunity to become immersed in the mourning process while walking through the graveyard. In doing so, the BWM counterbalances the stories of German perpetration and mass execution in the same room and allows for a universalized mourning of all victims of war.

Reflecting on the overall strategy of the BWM, the museum avoids the risk of simply recreating an empty form of reconciliation through its two-way approach

50 Often, the interviews were conducted by young people from Bastogne to create "an engaging and often very moving” intergenerational encounter (http://www.bastognewarmuseum.be/ press-kit.html, accessed 9 August 2018).

51 For video testimony in general see de Jong 2018a, especially chapter 4 "Exhibiting: The Witness to History as a Museum Object," 110-180. 
of integrating the local and the global. This leads to a constant use of distantiation. The global elements of the first section on the ground floor, including the first scenovision, are interwoven with local Belgian issues and the roles of Mathilde and Émile. The Belgian section on resistance and collaboration goes back and forth between these two sides and the occupiers. After this, the runthrough of the later events in the war across the globe, including D-Day, becomes very personal through the exhibition's collective perspective on the liberation of Belgium as well as the punishment of collaborators. Thus, visitors are well prepared for the more local view found in the basement, before they return to the world events, once more accompanied by the voices of the four characters at the end. In contrast to the New Orleans WWII Museum, the BWM thereby creates a balance between personal witness accounts, real and fictitious-composite characters, and a documentary overview of the war.

It is, however, important to note that the global here is not simply depicted through documentary panels and screens. The museum works with visualization techniques such as photo montages and enlarged photographs throughout the exhibition. It creates vanishing points through its photo posters. The very first artifact the museum visitor encounters is a wall collage of fourteen images presented in two rows of seven images, the top row in black and white and the bottom row colored in red. The images are often well-known icons, such as the staged picture of Germans opening a Polish border post on September 1, 1939, or the mushroom cloud after the nuclear bombing of Nagasaki, marking the beginning and the end of the war. Others refer to iconic historical moments, such as the Allied landing in Normandy, fleeing civilians, children in the Warsaw Ghetto, swastikas painted on the baldly-shaven heads of women accused of being collaborators, and piles of corpses and starved prisoners behind barbed wire in liberated concentration camps. All these moments, often with the same images, re-occur later in the exhibition. Thus, the visitor is prepared for the key emotional moments of the war. There is an emphasis on the Allied perspective, whether during their military advance, through civilian suffering, or during the discovery of the camps. This internal commentary effect is similar to the constant repetition in New Orleans; however, the New Orleans WWII Museum multiplies facts and core narratives and never leaves these to the open effects of images. ${ }^{52}$

In the first room, located above a Sherman tank, the visitor finds a slideshow of about twenty photographs that have been digitized to give the illusion of being a moving image. These images, surrounded by key words about the war in French, English, and German, repeat the exhibition's reference to some of

52 See also chapter 4.1. 
the war's major world events and also include specific images of the Battle of Bulge. Although visitors have not yet read any text about the war, they are already immersed in the core images of the war on both a local and global scale. Thus, the museum does not reconstruct the war through images, but uses images to create experientiality via iconic memory, various perspectives, structural contrasts, and narrative lines. For example, the main focus of the sixth room of the permanent exhibition - before the beginning of the Battle of the Bulge - depicts the road to liberation after D-Day. It presents the liberation of French and mostly Belgian cities from the perspective of the Belgian people. At its very end, the visitor encounters a model of a Willys Jeep that, according to its description, is as "emblematic of the Second World War and as famous as the Coca-Cola bottle.” The sidewall of this liberation room ends in a photo of waving Belgians in Antwerp and the film posters for The Dictator and Casablanca. In the back to the left of the jeep, an enlarged poster photograph of a Willys Jeep from the arrival of American soldiers in Branchon is displayed. Six children with happy, somewhat shy, and excited expressions are riding the jeep; a young girl on the lap of an African-American soldier is holding the wheel. To the right, the smiling boy in the back of the jeep is even further enlarged. The fact that Émile tells the exact same story in the audio guide, about how he is allowed to ride a jeep and receives chewing gum for the first time in his life, intensifies the emotional effect on the visitor. Émile becomes even more real. The exhibition visualizes war here with an emphasis on civilians' happiness surrounding the liberation. The iconic vehicle of the liberator merges with American consumer culture and Belgian youth, displaying the idea of a new beginning accompanied by jazz music. War is not primarily visualized through authentic reconstruction but through capturing and simulating an atmospheric moment. The transfer to the next room, which focuses on the German preparations for their surprise counter attack and the devastation it inflicted on civilians in the Ardennes, who had to once more flee or endure fighting, also begins with a symbolic visualization. If visitors turn around, they will see three posters: the still-smiling boy in the jeep, an enlarged portrait of Hitler, and a large poster of a swastika. The affective contrast could not be larger; it simulates the emotional letdown of the people in Bastogne and the surrounding region when the war starts up again.

The BWM employs an authenticating networking technique by interweaving numerous stories, images, eyewitness accounts, staged constellations, and objects. The reality effect is not simply created through the four fictitious composite characters. Instead, they interact closely with all other parts, sources, and media in the museum. All of these elements authenticate each other, while also diver- 
sifying and sometimes counterbalancing the narrative..$^{53}$ The museum's factual techniques, however, risk immersing visitors in a way that prevents them from realizing that these characters are constructed, composite perspectives of the war. This is the standard challenge and also potential objective for the museums analyzed in this section, which mainly create primary experientiality. Despite the distantiation techniques that the BWM uses, visitors are immersed in a historical simulation and can lose their reflexive and analytical skills for interpreting history and the many different perspectives it can offer.

53 Several professionals I talked to after their first visit to the museum felt that the four characters were real historical figures. 